\title{
人造グラファイト材料の高温物性計測技術開発 とそれを用いた解析
}

\section{Development of high temperature property measurements for artificial graphite materials and their analysis}

\section{岩下哲雄 ${ }^{a), *}$}

Norio IWASHITA ${ }^{\text {a),* }}$

\begin{abstract}
Many artificial graphite materials are utilized at a high temperature for smelting and refining metals, such as steel and aluminum, and for manufacturing silicon semiconductors. For such applications, it is important to understand the physical properties of these materials at high temperatures. Special instruments for measuring physical properties, such as the mechanical strength, creep, electrical resistance, thermal diffusivity and thermal expansion of artificial graphite materials from ambient to $2600^{\circ} \mathrm{C}$ have been developed and are introduced here. Experimental results obtained using these instruments and their analysis are reported.
\end{abstract}

KEYWORDS : Artificial graphite, High temperature property, Mechanical test, Creep test, Electrical resistance, Thermal conductance, Thermal expansion

\section{1.はじめに}

化石資源（石油・石炭）を燃料抢よび高炉用コークスなどの 化成品の原料として使用したあとの残渣は，有効に利用され， コークスやピッチが精製されている。それらを主原料素材とし て, 混合 (捏合) ・成型㧍よび炭素化 (焼成) し，さらに黒鉛 化と呼ばれる電気エネルギーによる $3000{ }^{\circ} \mathrm{C}$ 近くの超高温度の 熱処理を経て，目的製品である工業用カーボン材料が得られて いる。人造グラファイト材料は，半導体製造，電炉製鋼，金属 アルミニウム・金属マグネシウム精錬など高温・還元䨌囲気で かつ導電性を必要とする工業に必要不可欠な材料である。しか しながら，人造グラファイト材料は，それらの目的製品を製造 するにあたって発熱体，るつほ，アーク電極抢よび溶融塩電解 電極などに用いられ，酸化・消耗していくだけのスポットライ トの当たらない材料で，まさに黒衣（くろご）のような存在で ある。そして，見た目はただの黑物であるが，骨材となるコー クスの形状抢よび性状，カーボンブラックなどの添加や炭素繊 維による補強，さらに成型方法や最終熱処理工程の違いによっ て実にバラエティーに富んだ人造グラファイト材料が調製さ れている。人造グラファイト材料については，室伏の解説 ${ }^{11} に$ 2011 年の市場規模などが記載されており，電炉製鋼用人造グ ラファイト電極が全世界で 130 万トン／年製造され，およそ 4 億トンの電炉鋼製造に使われている。等方性グラファイト材料
は 2011 年当時 5 万トン $/$ 年と推定されており，市場規模は現在 も拡大の傾向にある。

我が国のカーボン材料の関連製造業は，ニードルコークスや ピッチコークス製造などの化石資源の有効活用から炭素化拉よ び黒鉛化工程の精密な制御などにおいて世界的にも高い技術を 有して扔り，これらの技術は，炭素繊維抢よびナノカーボン材 料の技術開発分野に波及していると言っても過言ではない。

カーボン業界の川下製造業者であるシリコン製造，電炉製 鋼，アルミ精錬の装置は，効率の追求により，大電流による急 速な加熱や精密な温度制御が要請されるようになってきた。そ こで，人造グラファイト材料は，高温において高い機械的強度 や高い耐久性などが要求されるだけでなく，信頼性のある高温 物性值の計測データが求められている。モデリングなどの計算 機支援工学(computer aided engineering, CAE)だけでなく，ライ フサイクルアセスメント (life cycle assessment, LCA)の観点から も，様々な工業用カーボン材料の高温における物理諸特性の計 測デー夕を取得し，技術デー夕を蓄積することは，工業用カー ボン材料の製造業だけでなく，半導体製造や電炉製鋼の製造業 の省エネルギーやコスト削減において非常に重要である。

\section{2. 計測する物性}

高温で使用される人造グラファイト材料の耐熱衝撃性などの 性能を向上するために，できるだけ高い熱伝導性，高い材料力

* Corresponding Author, E-mail: n-iwashita@aist.go.jp

(平成31年3月5日受理, 平成31年4月12日採択)

a) 国立研究開発法人産業技術総合研究所計量標準総合センター分析計測標準研究部門：干305-8569 茨城県つくば市小野川16-1

Research Institute for Measurement and Analytical Instrumentation, National Metrology Institute of Japan, NMIJ, National Institute of Advanced Industrial Science and Technology. AIST: 16-1 Onogawa, Tsukuba, Ibaraki 305-8569, Japan

http://dx.doi.org/10.7209/tanso.2019.91 

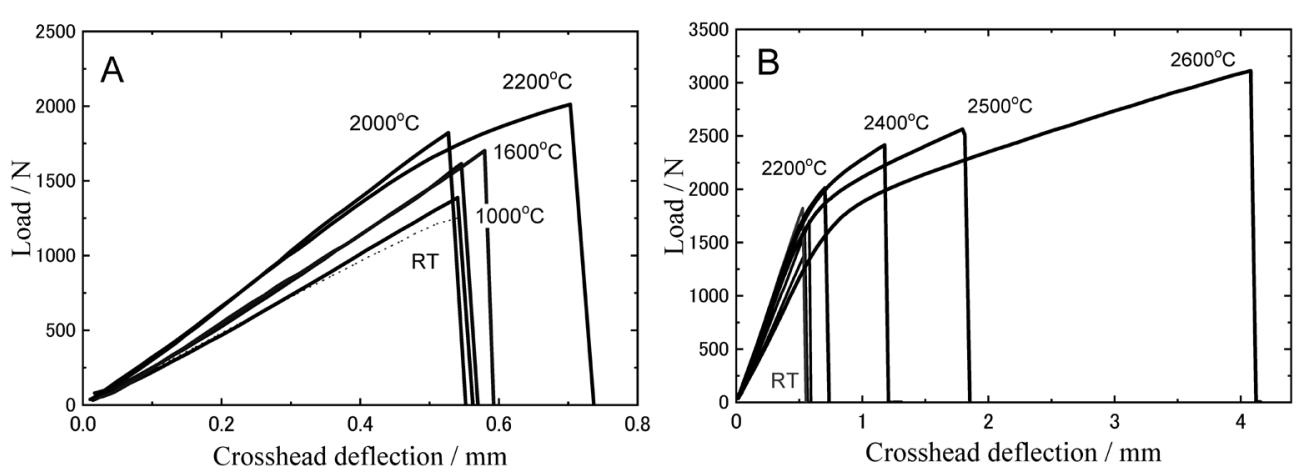

Fig. 1 Load-displacement curves for tensile test of isotropic graphite block IGS743 at different test temperatures. A: from room temperature (RT) to $2200^{\circ} \mathrm{C}$, B: from RT to $2600^{\circ} \mathrm{C}$. Reprinted from Ref. 3. Copyright 2011 Material Testing Research Association of Japan.

学的強度を示す一方で低い弾性率, 小さい熱膨張, そして電気 抵抗が低い材料を調製することが望まれてきた。これらの物性 の評価は基本的に常温での計測值で行われているが，的確な材 料評価のためには, これら物性值の使用環境である高温域まで の変化が重要である。

筆者の所属していた産業技術総合研究所の前身のひとつであ る大阪工業技術試験所（大工試）では，1988年から1992年の 間に官民連带共同研究として「炭素拉よび炭素ハイブリッド複 合材料の物理測定の評価・向上に関する研究」2) を実施し，常 温から $3000{ }^{\circ} \mathrm{C}$ 付近の超高温度域までの材料力学的強度, 電気 抵抗，熱拡散率を計測する試験装置を開発し，種々の炭素材料 および炭素瀻維複合材料の高温物性について評価を行ってき た。その後, 筆者は, この共同研究で得られた試験技術の経験 を活かして試験装置や手法を改良し，様々な人造グラファイト 材料の高温での材料試験を比較的簡便するための改良，また得 られた試験データの解析などを行ってきた。

この論文では，高温での材料力学試験のほか，電気抵抗，熱 拡散率损よび熱澎張の試験手法を紹介するとともに，人造グラ ファイト材料を含む実際の工業用カーボン材料の解析結果を示 す。

\section{3. 材料力学試験}

\section{1 高温引張試験と超高温クリープ試験 33,4$)$}

人造グラファイト材料は, 高温域になると材料力学的強度 が増強することが知られている。等方性グラファイト材料 (IGS743)の常温から $2600{ }^{\circ} \mathrm{C}$ までのアゴン䨌囲気中における 引張試験に扔ける荷重-変位曲線を Fig. 1 に示す ${ }^{3)}$ 。人造グラ ファイト材料の材料力学的強度は, 常温での試験でも酸素や水 分の影響を受けて低下することが知られている5)。そこで，本 研究の場合, 常温での引張試験においても, 真空脱気の後, ガ ス置換したアルゴンガス雾囲気で行った。ガラスやセラミック スと同じように脆性材料である人造グラファイトは，常温で は弾性変形の限界に到達する前に破断する(Fig. 1A)。引張強度 は，試験温度が高くなると増加していることが伺える。さらに 高温になり $2200{ }^{\circ} \mathrm{C}$ を超えると, 金属材料のように塑性変形に ともなう非線形挙動を示すようになり，破断するまでの変形量
が著しく大きくなる(Fig. 1B)。室温での試験と比較すると，試

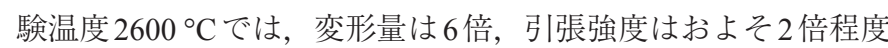
に相当する。

このように人造グラファイト材料は，高温で強度が増加する ので，局部加熱による強度試験を行うと，温度の高い部分では なく比較的温度の低い部分が破壊するので，正しい高温強度が 得られない。そこで，炭素材料の材料試験は，試験片だけでな く試験ジグの部分も試験温度に加熱する必要がある。これは, 人造グラファイト材料の高温での材料力学試験の困難さを示唆 している。

この引張試験で用いた試験片を試験ジグに装着した電気炉内 部の様子をFig. 2 に示す。一連の高温物性計測において使用し ている超高温炉は，(株)倉田技研製で，グラファイト製のヒー ターにより加熱し，最高温度が拈よそ $3000{ }^{\circ} \mathrm{C}$ に到達する。そ の周囲が等方性カーボンファイバーからなる成形断熱材で覆 われている。ダンベル型試験片 (Fig. 2B)の中央細部の直径は, $6 \mathrm{~mm}$ ，ゲージ長さが $15 \mathrm{~mm}$ である。試験片の両端部には，試 験ジグに引つ掛けるための鍵型の部位を作っている。この部分 を含めて全長が $120 \mathrm{~mm}$ になる。等方性グラファイト材料で作 製した試験ジグのところから試験片全体を加熱している。

人造グラファイト材料が高温になると材料力学的強度が増強 するメカニズムは，Mrozowskiが1950年代に提唱した説が一般 的である ${ }^{6}$ 。それは，人造グラファイト材料が $3000{ }^{\circ} \mathrm{C}$ 付近の 熱処理プロセスによってグラファイト結晶化と体積収縮が生じ て，その後常温まで泠却されるため試料内部には非常に多くの マイクロクラックが存在し，そのマイクロクラックが再加熱の 熱澎張によって閉じるために, 高温で強度や弾性率が高くなる という説である。

しかしながら， $2200{ }^{\circ} \mathrm{C}$ 以上の試験温度では，引張弾性率に 相当する荷重-変位曲線の傾きが小さくなる。そして, 塑性変 形にともなう非線形挙動が観察される。この $2200{ }^{\circ} \mathrm{C}$ を境にし て, 試験片の破断の様子も変化する。試験温度 $2000^{\circ} \mathrm{C}$ 以下の 破断面は，比較的平滑であるが，塑性変形を示した $2200^{\circ} \mathrm{C}$ 以 上では引張応力を受けている直径 $6 \mathrm{~mm}$ の細部が砕けたような 凹凸のある破断面となる ${ }^{3)}$ 。

この $2200{ }^{\circ} \mathrm{C}$ は，グラファイトおよびダイヤモンドの Debye 

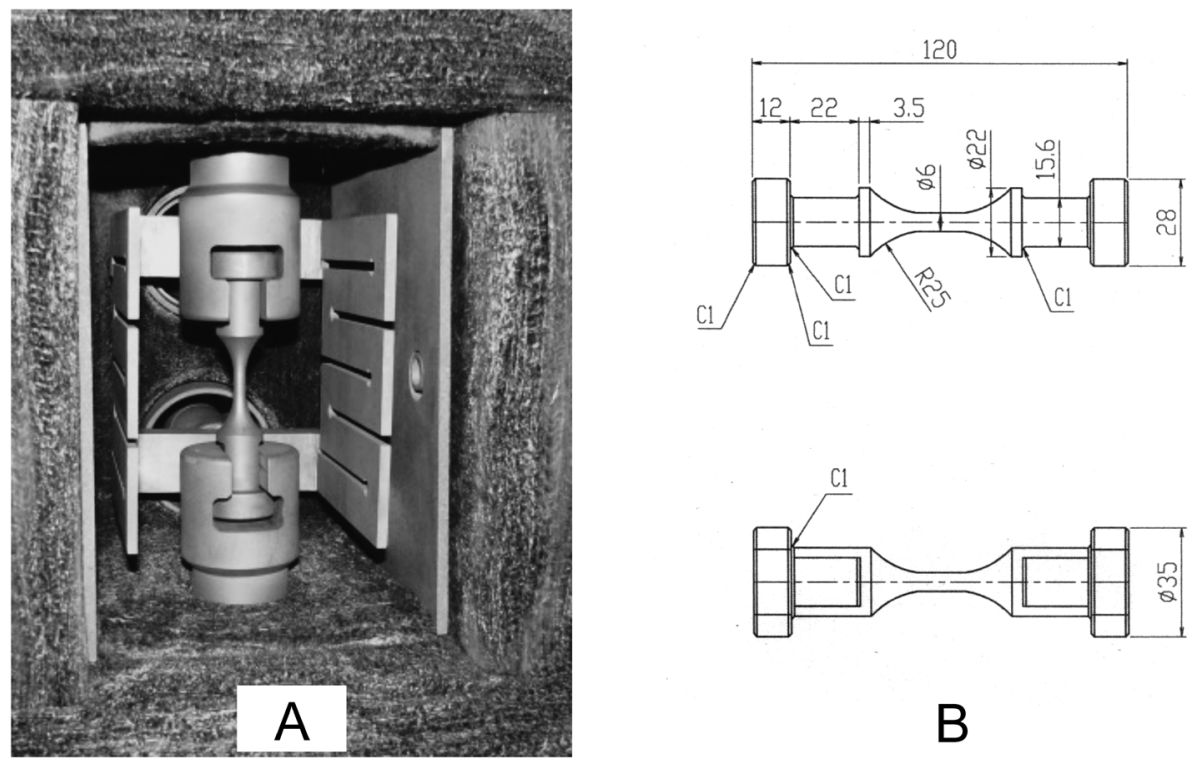

B

Fig. 2 A: View of tensile test specimen set into jigs in high temperature electrical furnace and B: Specimen design of high temperature tensile test of carbon materials. Reprinted from Ref. 3. Copyright 2011 Material Testing Research Association of Japan.
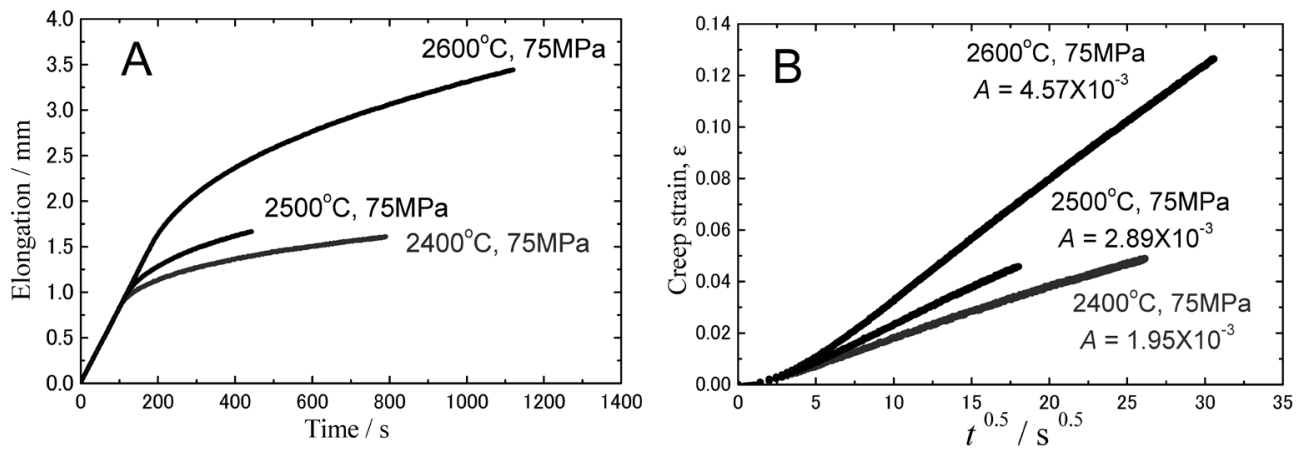

Fig. 3 Results of high temperature tensile creep test of isotropic graphite block IGS743. A: Elongation versus test time curves and B: Plots of creep strain versus $t^{0.5}$ under different temperatures. Reprinted from Ref. 3. Copyright 2011 Material Testing Research Association of Japan.

温度に相当する。Debye温度以上では，炭素-炭素の共有結合の 振動数が最大值で飽和した状態になる。金属材料と同様に，弾 性変形の限界に到達するとグラファイト結晶内で転移が応力に より生じたと考えられている。実際に，非常に結晶性の良い熱 分解カーボン試料を用いて, 超高温での転移の動きを実際に観 察した例もある77,8)。

成澤らは，前述の官民連帯共同研究 ${ }^{2)} に$ 扔いて，別の種類の 等方性グラファイト材料(IG11)を用いて, $2400 \sim 2600{ }^{\circ} \mathrm{C}$ 超 高温クリープ試験で塑性変形をしたサンプル細部の超音波の伝 達速度を調べたところ，音速が最大で $20 \%$ も低下することを 見いだした9),10)。これは, 黒鉛結晶の基底面(basal plane) に転移 が多量に発生したことに起因して，それにともなう粒界のす心゙ りがクリープ変形速度を支配していると考察されている。

$2400{ }^{\circ} \mathrm{C}$ 以上の試験温度では，非線形挙動を示す荷重での超 高温クリープ試験を行った ${ }^{3,4,4) 11}$ 。顕著なクリープ現象が観察 される荷重は，常温で破断する荷重值よりずっと高い。そのた め目的の温度へ昇温させた後に荷重を試験片に負荷させた。試 験ジグおよび試験機へのダメージのリスクを考慮して, 引張試
験と同様に $0.5 \mathrm{~mm} / \mathrm{min}$ のスピードでクロスヘッドを移動させ て, 目的の荷重まで到達した後の伸びの時間依存性を計測した。 クリープ試験の伸び-時間曲線を Fig. 3A に示す。目的の負荷 (75 MPa)に到達するまで試験機のクロスヘッドを移動させ，荷 重到達後は，負荷を一定にするためにクロスヘッドを制御させ たときの曲線である。目的の荷重に到達した時点を起点とし て，歪み量の時間変化を Fig. 3Bに再プロットした。

クリープ曲線は，一般的に用いられるクリープ歪み $を と$ 時間 $t$ の関係式から解析を試みた。

$$
\varepsilon=A t^{n}+B
$$

ここで, カーボン材料の場合, 時間の乗数 $n$ は, グラファイト 結晶の配向と応力を負荷する方向に依存して $0.3 \sim 0.7$ の幅で変 動するとされている7)。今回用いたカーボン材料は，等方性で あるので, $n=0.5$ と仮定して，Fig. 3Bの時間軸は， $t^{0.5}$ でプロッ トした。

試験温度が高くなるについてクリープ変形速度が早くなるこ

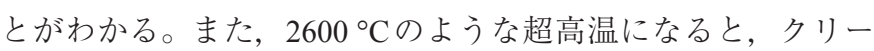



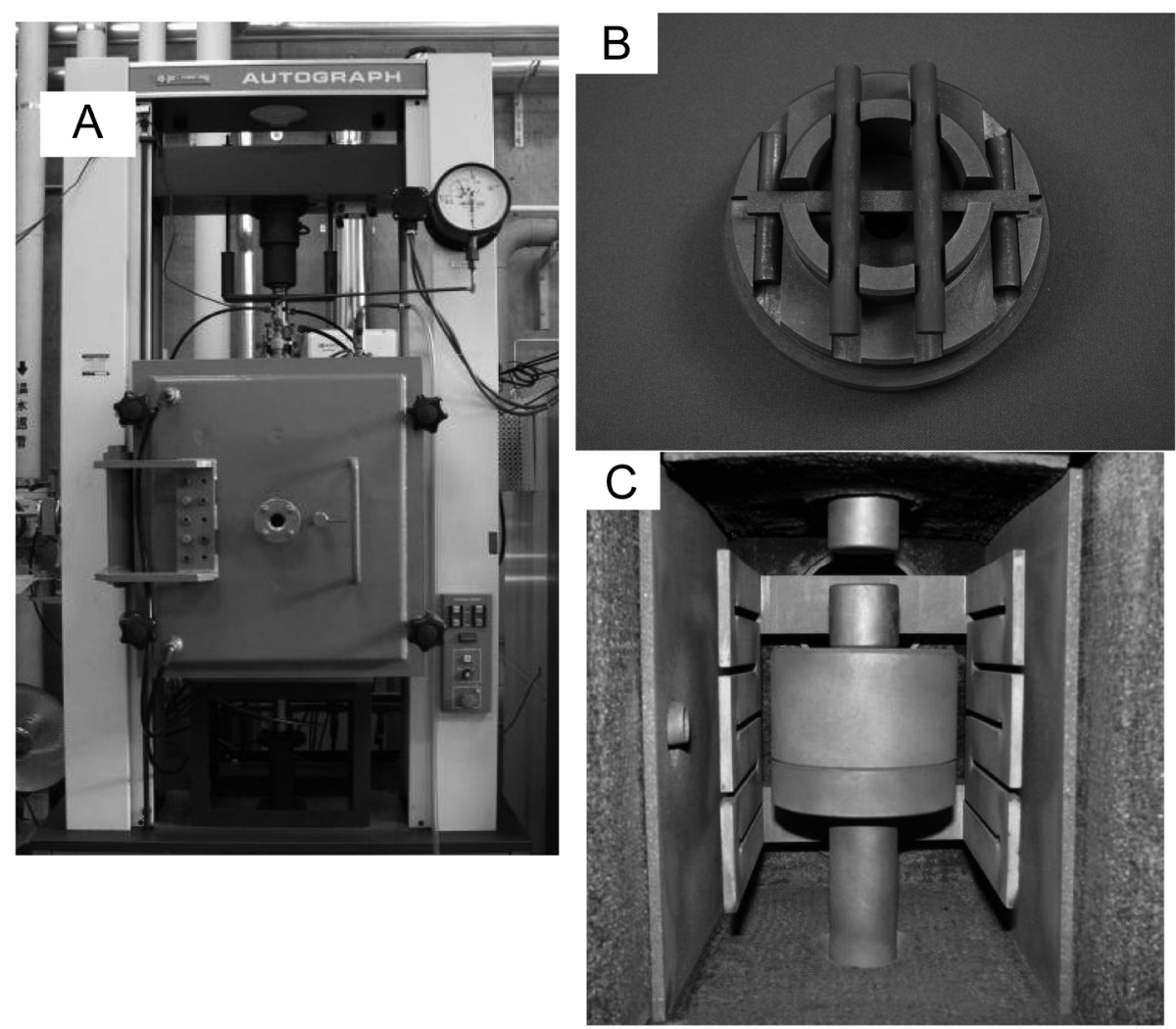

Fig. 4 Photos of A: View of test machine equipment of bending test at high temperatures, B: Bending jig set in the furnace and C: View of bending test jig. Reprinted from Ref. 12. Copyright 2008 Material Testing Research Association of Japan.

プ速度は負荷される応力にも敏感になってくる。二次クリープ

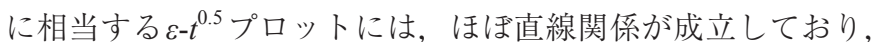
この直線近似からクリープ係数 $A$ を求めて図中に記述した。

これまでに多種類の等方性グラファイト材料の高温引張試験 および超高温クリープ試験を行って，カーボン材料の種類に よって，高温引張強度や超高温クリープ変形係数が異なること がわかっている4),11)。現在，超高温クリープ変形速度に影響す る因子を探っている。

\section{2 高温曲(゙゙試験 ${ }^{12)-15)}$}

先に紹介した高温引張試験では複雑な形状の試験片を加工す るなどの費用と手間が必要である。実際に試験片の加工費に は1本数十万円を費やす。そこで，高温での材料力学強度を評 価するには試験片の加工が比較的容易な短冊状試験片を用いて いる。高温で試験片が「たわむ」現象を観察するために四点曲 げ試験を実施している。材料試験機の外観と電気炉内にセット

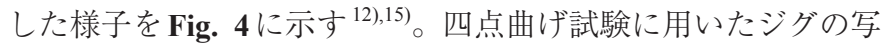
真をFig. 4B に示している。この台座となるジグも支点掞よび 負荷圧子の丸棒も等方性グラファイト材料で作製されている。 試験片の形状は $2.5 \times 5 \times 65 \mathrm{~mm}$ をべースとした。四点曲げ試験 は, 支点間距離： $51 \mathrm{~mm}$, 圧子間距離 : $17 \mathrm{~mm}$ とし, 支点抢よ び圧子の直径は $6 \mathrm{~mm}$ である。

高温試験は，破片飛散防止用にカバーをつけて，Fig. 4Cに 示すように電気炉内にセットして行った。試験のクロスヘッド スピードは，0.5, 0.2 抢よび $0.1 \mathrm{~mm} / \mathrm{min} の 3$ 段階とした。測定の

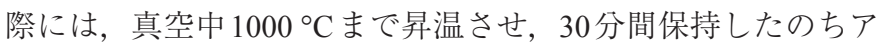

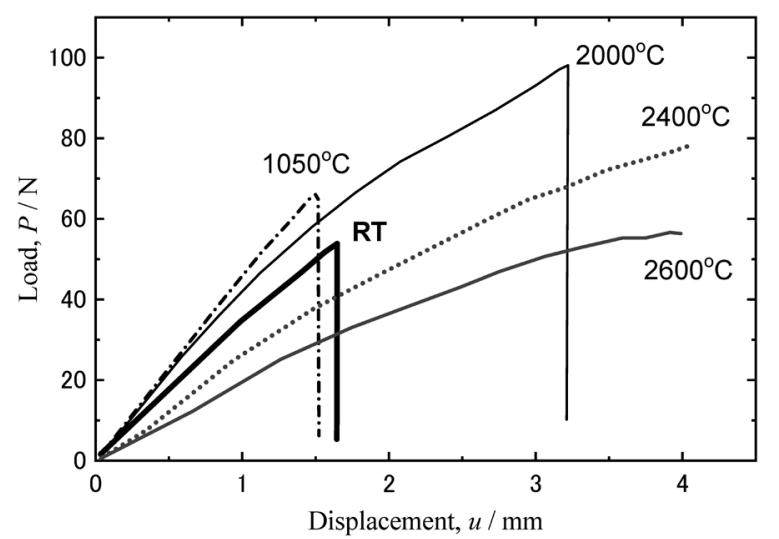

Fig. 5 Load-displacement curves of isotropic graphite block ISO88 during the bending test at different temperatures. Reprinted from Ref. 12. Copyright 2008 Material Testing Research Association of Japan.

ルゴンガスを導入し，目的の温度（室温から $2600{ }^{\circ} \mathrm{C} ）$ 一昇温 させて 15 分間保持後に負荷を開始した。変位として，クロス ヘッドの移動量を測定した。

等方性グラファイト材料ISO 88 の様々な試験温度での曲げ試 験の荷重-変位曲線を Fig. 5 に，曲げ強度と弾性率の試験温度依 存性プロットをFig. 6 に示す ${ }^{12)}$ 。ISO88 の室温に打ける曲げ強

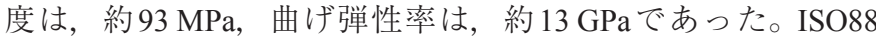
の曲げ強度は， $1000{ }^{\circ} \mathrm{C}$ から $2000{ }^{\circ} \mathrm{C}$ の試験温度範囲で試験温

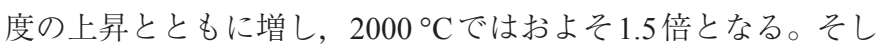
て，試験温度が $2400{ }^{\circ} \mathrm{C}$ 以上になると試料は脆性的に破断しな 

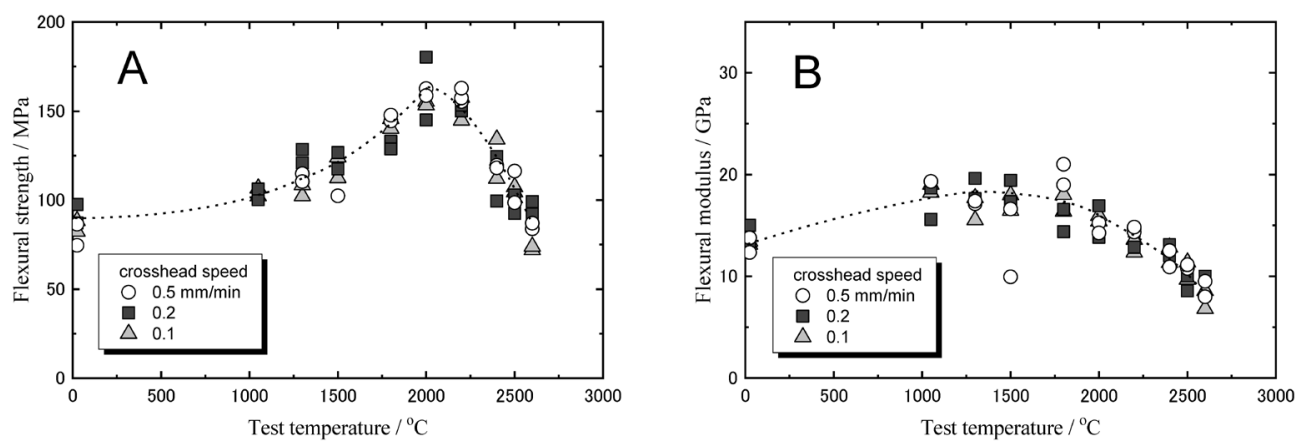

Fig. 6 A: Dependences of flexural A: strength and B: modulus of isotropic graphite block ISO88 on test temperature. Reprinted from Ref. 12. Copyright 2008 Material Testing Research Association of Japan.
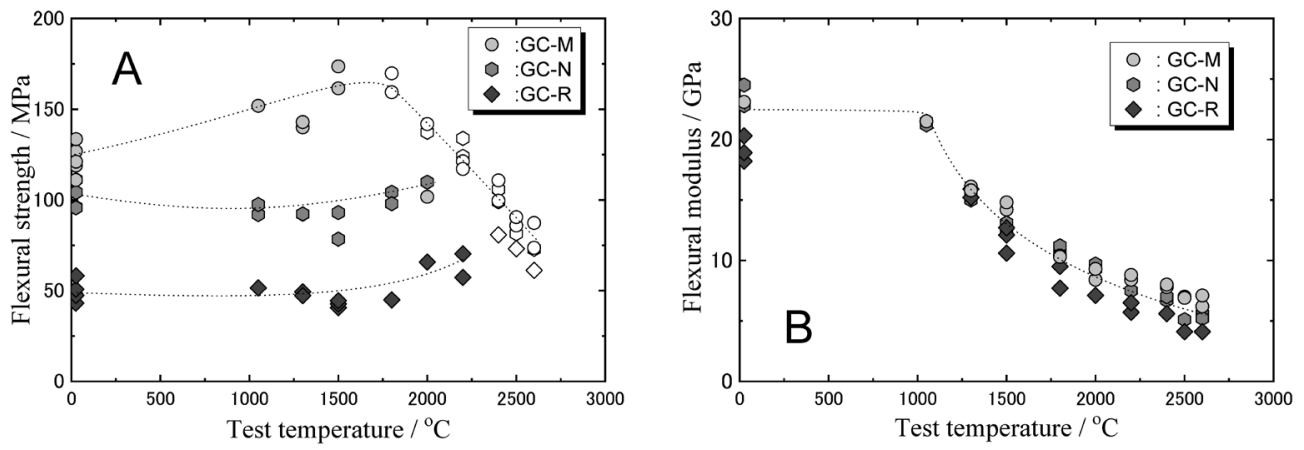

Fig. 7 A: Plots of flexural A: strength and B: modulus versus test temperature of glassy carbons with different surface roughness. A: Solid marks: broken and Open marks: no break points. Reprinted from Ref. 14. Copyright 2011 Material Testing Research Association of Japan.

くなった。試験温度 $2400{ }^{\circ} \mathrm{C}$ 以上の強度は，ジグ形状のたわみ 量の限界（拧よそ $4 \mathrm{~mm} ）$ に到達したときの荷重から算出され た值であり，曲げ強度とは言えないが，その試験温度において 試料に負荷できる応力值である。

他方，曲げ弾性率は，強度と同様に $1000{ }^{\circ} \mathrm{C}$ から $2200{ }^{\circ} \mathrm{C}$ の試 験温度範囲では室温の值より僅かに大きな值を示す。弾性率が 極大を示す試験温度は $1500{ }^{\circ} \mathrm{C}$ 付近である。 $2000{ }^{\circ} \mathrm{C}$ 以上の超高 温下では試験温度の上昇とともに弾性率が低下して，2200 ${ }^{\circ} \mathrm{C}$ 以上になると室温の試験より変形しやすくなっている。その結 果， $2400{ }^{\circ} \mathrm{C}$ 以上の曲げ試験では，グラファイト材料は曲げ応 力で破断しなくなり，塑性変形して，湾曲した試験片が得られ る $^{12)}$ 。

人造グラファイト材料の範疇ではないが，黒鉛化しにくい ハードカーボンの代表としてガラス状炭素 $\mathrm{GC} 10$ の高温曲げ試

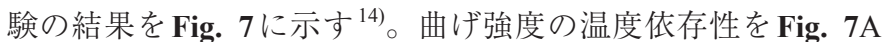
に，曲げ弾性率の温度依存性を Fig. 7Bにそれぞれ示す。この ガラス状炭素を用いた高温曲げ試験では, 試験片の表面の粗さ が高温曲げ強度に与える影響を調べた。サンプルコード GC-M は，ダイヤモンドスラリーを用いたバフ研磨により鏡面加工し たもの，サンプルコード GC-Nは，\#800の紙やすりで研磨加工 したもの，そして，サンプルコードGC-Rは，\#80の紙やすり で特別に表面加工したものである。

ガラス状炭素は黒鉛化しにくいことから，Mrozowski ${ }^{5)}$ がメ カニズムを提唱した人造グラファイト材料の強度および弾性率
が高温で高くなる現象がガラス状炭素でも生じるのか調べた。 常温での曲げ強度は，鏡面研磨された試験片 CG-Mが高く， 表面仕上げが粗くなると比較的低い応力で破断する。これは, 脆性材料の典型的な挙動である。ガラス炭素の曲げ試験の試験 温度が高温にシフトすると，試験片表面を鏡面研磨した GC-M は，試験温度の上昇とともに曲げ強度が高くなる傾向があり， 試験片表面に粗さがある GC-N と GC-Rでは，曲げ強度は試験 温度に依存しない結果が得られた。他方，高温における曲け弾 性率は，表面粗さに対しても試験温度に対しても影響がない結 果が得られた。

この試験で用いたガラス状炭素は，熱処理温度が $2000^{\circ} \mathrm{C}$ 以 下であり，また，ガラス状炭素自身が難黒鉛化性なので，熱処 理によってマイクロクラックが材料内部に生じていないと想 定される。したがって，Mrozowskiがメカニズムを提唱した人 造グラファイト材料の強度抢よび弾性率が高温で高くなる現象 は，ガラス状炭素では生じないという結論に達した。ただし， 試験片表面を鏡面研磨した GC-Mの場合に，ガラス状炭素の曲 げ強度が試験温度の上昇とともに高くなることについては，常 温での試験に扔いて強度低下の要因があったと考えているが, さらに検討が必要である。

曲げ弾性率の試験温度依存性は，カーボン材料のかさ密度

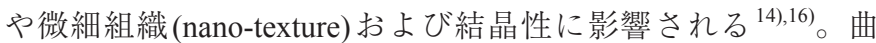
げ弾性率の温度依存性の特徵は，常温で弾性率の絶対值が高 い試料ほど，弾性率が低下に転じる温度が低くなることであ 
る。具体的には，常温での曲げ弾性率が 13 GPaのISO880では $1500{ }^{\circ} \mathrm{C}$ 以上から, 曲げ弾性率が $30 \mathrm{GPa}$ のガラス状炭素におい ては $1000{ }^{\circ} \mathrm{C}$ 付近から曲げ弾性率が低下する。むしろ, 常温で の曲げ弾性率が $8 \mathrm{GPa}$ 程度の沉用の等方性グラファイト材料で

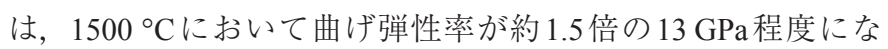
り，2000 ㄷ以上で低下する。Mrozowskiがメカニズムを提唱し た説に立ち返ると，黒鉛化プロセスにおいてマイクロクラック の発生が多い試料は，高温になると熱膨張によってマイクロク ラックが再び閉じることにより弾性率が高くなる“伸びしろ” が十分にあるとも言える。人造グラファイト材料の高温での曲 げ弾性率の変化は, 試料のかさ密度の值にも配慮する必要があ る。

このほかにも筆者は, 超高温の材料試験でしか観察されな

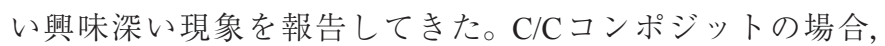
$2400{ }^{\circ} \mathrm{C}$ の高温で曲げ試験を行ったとき，炭素繊維が切断する ことなく屈曲し，金属を局部的に曲げたときに生じる座屈が圧 子の直下で観察され, 側面には出っ張りが生じる様子が観察さ れている ${ }^{13), 15) 。 ~}$

\section{4. 電気抵抗と熱伝導性}

人造グラファイト材料の応用では, 通電加熱して使用するこ とから，高温における人造グラファイト材料の電気的性質およ び熱的性質は非常に重要な因子である。

古くは1959年, 水島 ${ }^{17)}$ が4種類の人造黒鉛電極を電気炉中 $700{ }^{\circ} \mathrm{C}$ で電位差法にて, それ以上の温度では, 真空中, 直接 通電加熱し, タングステンの針にて電圧を測定し, 常温から $2500{ }^{\circ} \mathrm{C}$ までの電気抵抗率を計測し, 電気抵抗率の温度依存性 には極小值が存在することを報告している。大工試でも前述の 官民連帯共同研究 ${ }^{2)}$ において, 高温での電気抵抗および熱拡散 率を計測する試験機を開発した。近年は，岡田ら ${ }^{18)-20)}$ が直接 通電加熱による黑鉛ヒーターの高温電気抵抗率の測定結果を報 告している。

カーボン材料の高温での電気抵抗と熱伝導性の両方の温度 依存性の報告例は少なく，1970年代まで遡る。Lutcovら ${ }^{21)}$ は, 異なった嵪密度のグラファイトの $50 \sim 2500 \mathrm{~K}$ の電気抵抗，熱 伝導率，比熱容量を報告している。Bapat ${ }^{22), 23)}$ は，人造グラ

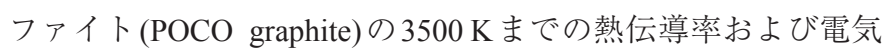
抵抗率を測定したことを報告している。ただし，これらの試験 結果をどのような装置を用いて計測されたかについては記述が ない。電気的および熱的両方の物性の温度依存性を計測し，そ の結果を解析する報告例は，少ないのが現状である。

\section{1 電気抵抗 ${ }^{12), 24), 25)}$}

かつては大工試での官民連帯共同研究で製作した高温電気抵 抗計測試験機 ${ }^{26)}$ が存在したが，1992年以降はトラブルが頻発し 廃棄となった。そこで，筆者が二号機を装置の設計から計測プ ログラムまで手作りした。非常に愛着のある試験装置である。

高温での電気抵抗計測装置の内部を Fig. 8 に示す ${ }^{12)}$ 。試験片 形状は， $10 \times 10 \times 120 \mathrm{~mm}$ の角棒を用いた。試験片をグラファ

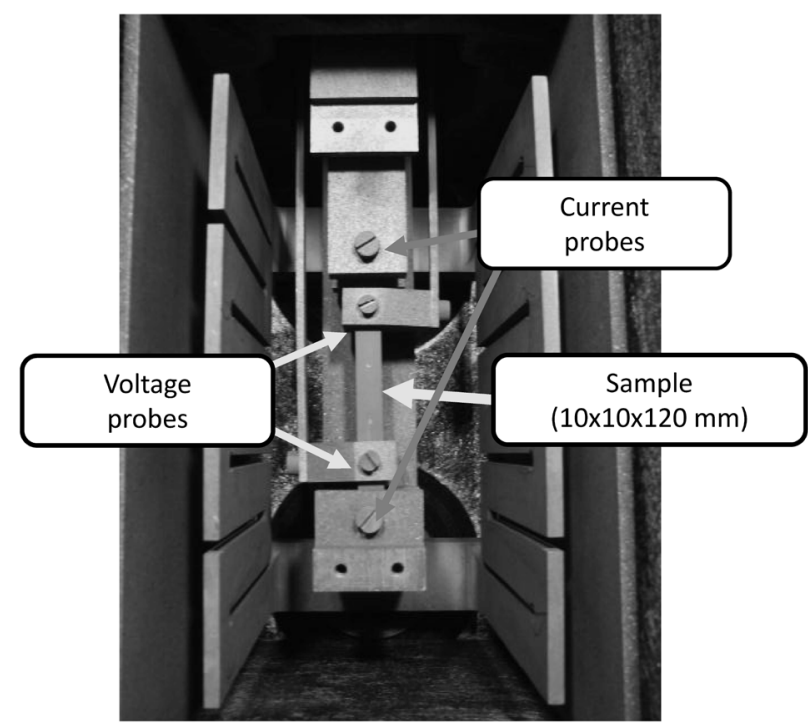

Fig. 8 Photo of sample holding jig in the furnace of test instrument for measurement of electrical resistance at high temperatures. This photo is taken the jig removed the front plate. Reprinted with permission from Ref. 24. Copyright 2013 Elsevier.

イト製のジグにねじで固定して，その周りをグラファイト製の ヒーターで昇温（または降温）しながら，四端子定電流法によ る電圧計測によって抵抗を求めた。電圧測定用端子は, 正面向 かって左右のスペースを利用して計測用グラファイト板を上か ら降ろして接続させている。電圧端子間距離は，51 mmとし， 電流端子と同様にねじで固定した。箱型電気炉の上部のフラン ジ接続した管状部に抵抗計測用のジグが装着され, ここから電 気信号の出し入れが行われている。計測用ジグは，アルミナセ ラミック板とボロンナイトライドなどを使用してそれぞれの端 子の絶縁を保っている。

計測は，電圧・電流発生器とデジタルマルチメーターをパソ コン制御し 60 秒間隔で行った。入力電流は $\pm 100 \mathrm{~mA}$ とし, 計 測するときだけ電流を流し，正負電圧の電位差から抵抗を算出 した。キャリブレーション用に標準抵抗器を準備し, 計測前に 毎回確認した。

電気炉内は，真空ポンプを用いてアルゴンガスまたは窒素 ガスに置換される。昇温・降温速度は，20 ${ }^{\circ} \mathrm{C} / \mathrm{min}$ とし，2500 $2600{ }^{\circ} \mathrm{C}$ の温度で $5 \sim 10$ 分間保持した。電気炉温度の制御は, 光温度計を用いて行った。電気炉内の温度計測は, $1000{ }^{\circ} \mathrm{C}$ 以 上の高温ではヒーターの温度を光温度計で計測し， $1200{ }^{\circ} \mathrm{C}$ 以 下の温度は，熱電対を用いてモニターした。

アルゴンガス䨌囲気で $2000{ }^{\circ} \mathrm{C}$ 超えた高温抵抗を計測した ときに，灰分など不純物が存在すると異常な抵抗の低下が観察 されることが岡田らによって報告されている ${ }^{19), 20) 。 こ の ア ル コ ゙ ~}$ ンガス雰囲気における高温抵抗の低下は, 先の共同研究におい て製作した高温電気抵抗計測装置一号機においても観察されて

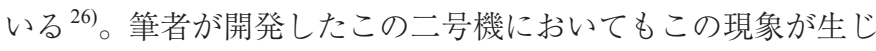
るかを確認した。この装置で計測した等方性グラファイト材料 ET-10の電気抵抗の温度依存性を Fig. 9に示す。窒素ガスとア 


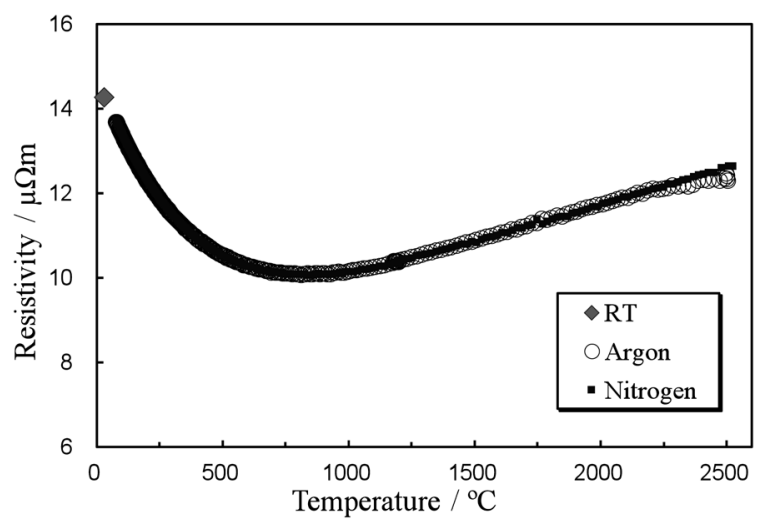

Fig. 9 Temperature dependences of electrical resistivity of isotropic graphite ET-10 on furnace temperature.

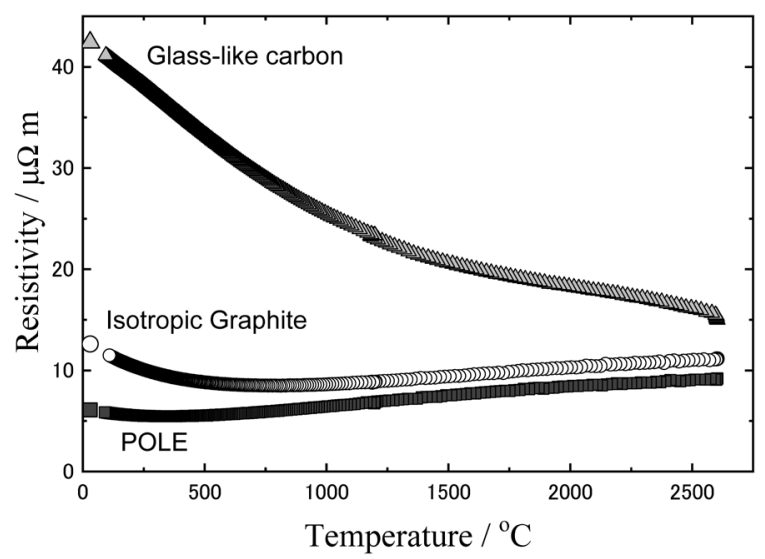

Fig. 10 Temperature dependences of resistivity of glass-like carbon, isotropic graphite block IGS743 and artificial graphite electrode (POLE). Reprinted from Ref. 12. Copyright 2008 Material Testing Research Association of Japan.

ルゴンガス雲囲気でほとんど差異が観察されないが， $2300{ }^{\circ} \mathrm{C}$ 以上においてアルゴンガス雲囲気の高温抵抗が僅かに低くなっ ている。現在, 試験装置内の不純物をできる限り排除して, ア ルゴンガス雲囲気での異常な高温抵抗の低下ができるだけ出現 しない環境を整えている。この論文で紹介する試験結果は, す ベてアルゴンガス雲囲気中での計測結果である。今は, 必要に 応じて, 窒素ガスおよびアルゴンガス両方の雲囲気中での高温 抵抗を計測し，結果を比較して確認するようにしている。

この計測装置から得られた各種のカーボン材料（ガラス状炭 素, 等方性グラファイト材料 IGS743 および人造グラファイト 電極(POLE)）の抵抗率の温度依存性を Fig. 10に示す。カーボ ン材料の電気抵抗は, 常温からある温度まで小さくなるが, 等 方性グラファイト材料およびPOLEの場合, その挙動はその温 度で反転して, 温度上昇とともに抵抗值が大きくなる。この現 象は, 常温から数百 ${ }^{\circ} \mathrm{C}$ の温度範囲の計測結果から $1000{ }^{\circ} \mathrm{C}$ 以上 の高温抵抗值を推定することが困難であることを意味する。こ のような複雑な電気抵抗の温度依存性は, 人造グラファイト材 料の特有の挙動である。

ガラス状炭素は, 難黒鉛化性炭素の典型であり, 常温では抵 抗率が高く, 温度上昇とともに抵抗が低下する半導体的性質

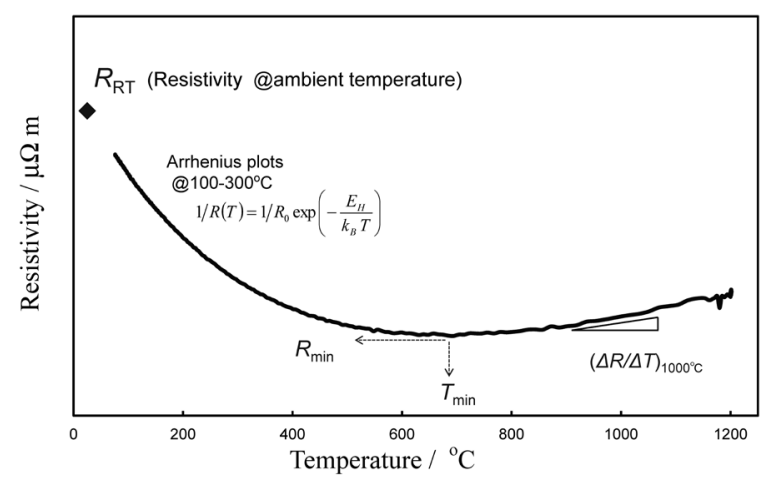

Fig. 11 An example of temperature dependence curve of electrical resistance of artificial graphite product and some specialty parameters estimated from the curves. Reprinted with permission from Ref. 24. Copyright 2013 Elsevier.

を示す。ガラス状炭素は, グラファイト結晶が発達していない ので，電導キャリアが少なく，キャリアの易動度も小さい。ガ ラス状炭素の高温電気抵抗は，熱励起による電導キャリアの 増加が主として起きるために低下する傾向を示している。こ れらカーボン材料の電気抵抗の温度依存性の挙動を眺めると, $3000{ }^{\circ} \mathrm{C}$ 近くの超高温になるとカーボン材料の電気抵抗は結晶 性などに影響されなくなるのではないかと予想される。

高温電気抵抗の計測試験結果の分析は, カーボンメーカーか ら提供された複数のサンプルで実行し，得られた電気抵抗の温 度依存性をX線粉末回折(XRD)による結晶構造パラメータを用 いて解析することに主眼をおいてきた。

SECカーボン社との共同研究 ${ }^{24)}$ では，押出し成形によって 調製された 12 種類の人造グラファイトブロックの常温から $1200{ }^{\circ} \mathrm{C}$ までの電気抵抗の温度依存性を計測して，JIS R7651 法 (通称：XRD学振法) ${ }^{27-29)}$ によって得られる結晶構造パラメー 夕および黑鉛化度 $P_{1}{ }^{30)-33)}$ を用いて解析した。解析するにあた り, 電気抵抗の温度依存性曲線を Fig. 11 のように五つの因子 によって定義づけした。

(1)常温における抵抗率の值 $R_{\mathrm{RT}}$

(2) $100 \sim 300{ }^{\circ} \mathrm{C}$ における熱励起による抵抗の低下の温度依存性 をアレニウスプロットして求めた「活性化エネルギー」 $E_{\mathrm{H}}$

(3)抵抗率が極小值を示す温度 $T_{\min }$

(4)極小抵抗率を常温の抵抗率で除した「極小相対值」 $R_{\min }$ / $R_{\mathrm{RT}}$

(5)極小值を超えた温度域での抵抗上昇における傾き（文献 24 の場合は $1000{ }^{\circ} \mathrm{C}$ における傾き $)(\Delta R / \Delta T)_{1000}{ }^{\circ} \mathrm{C}$

12 種類の人造グラファイトブロックは，黒鉛化度 $P_{1}$ が 0.50 から 0.65 , 炭素六角網面層の平均面間隔 $d_{002}$ が $0.336 \sim 0.338 \mathrm{~nm}$ の範疇のものであった。これらの五つの因子と結晶構造パラ メータの間には，以下の関係が成立した。

（1）常温での抵抗率は, 三次元積層秩序を表す黒鉛化度 $P_{1}$ と非常に良い相関関係が存在した。他方，平均面間隔 $d_{002}$ 值はフィラーコークスの黒鉛化性が良い部分だけを 反映するために，抵抗率との相関関係から大きく外れる 
試料もあった。

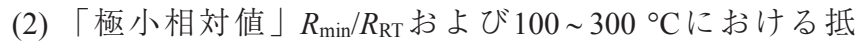
抗の低下の「活性化エネルギー」 $E_{\mathrm{H}}$ の值は, 平均面間 隔 $d_{002}$ の值と良い相関が得られた。具体的には $d_{002}$ 值が $0.3354 \mathrm{~nm}$ から大きい值になるにつれて，抵抗の低下す る割合 $R_{\min } / R_{\mathrm{RT}}$ は小さくなり, 活性化エネルギーは大き くなる。常温から $500{ }^{\circ} \mathrm{C}$ 程度までの温度上昇による抵 抗の低下は，積層の乱れによって常温では導電に寄与し ていなかった $\pi$ 電子（または正孔）が熱励起によって導 電キャリアとして寄与するようになり，導電キャリア数 が増加した結果と考えられる。

(3) 極小值を示す温度 $T_{\min }$ および抵抗上昇の傾き $(\Delta R / \Delta T)_{1000}{ }^{\circ} \mathrm{C}$ は，黒鉛化度 $P_{1}$ または炭素六角網面の結晶子サイズ $(\mathrm{La})$ と相関があった。具体的には， $T_{\min }$ は，三次元積層秩序 が増し，炭素六角網面が大きいほど低温側にシフトし， 抵抗上昇の傾き $(\Delta R / \Delta T)_{1000}{ }^{\circ} \mathrm{C}$ は $P_{1}$ および $L \mathrm{a}$ の増加とと もに高くなる。これら人造グラファイトブロックにおい て $1000{ }^{\circ} \mathrm{C} て ゙$ 抵抗が温度上昇とともに増加する現象は, 電導キャリアの熱振動による散乱に起因していると考え られる。

この(2)と(3)のメカニズムが異なる温度領域で生じ，そし て相殺されるために，人造グラファイト材料の高温抵抗の温 度依存性は，ある任意の温度で極小值を示す。(2)の常温から $800{ }^{\circ} \mathrm{C}$ 以下の温度までの熱励起による抵抗の低下は，グラファ イト結晶構造の乱れとともに強調され, 他方, (3)の高温域に おける抵抗増加は，結晶子サイズが大きく，黒鉛化度 $P_{1}$ が高 い試料ほど，高温での熱振動による散乱の影響を受けやすい。 以上の結果および考察から，人造グラファイト材料の高温抵抗 の温度依存性は，原料フィラーコークスの特性（粒の大きさ， 黒鉛化性，配向性など）に影響することが理解される。

新日本テクノカーボン社との共同研究 ${ }^{25)}$ では, 冷間等方プ レス(CIP)成形によって調製された 5 種類の等方性グラファイ 卜材料 $(\mathrm{A} \sim \mathrm{E})$ の高温電気抵抗および熱伝導性の温度依存性を 計測し，等方性グラファイト材料の調製条件が結晶性，さらに は高温での電気抵抗および熱伝導性の温度依存性に結晶性が与 える影響を調べた。Table 1 に 5 種類の等方性グラファイト材料 の平均面間隔 $\left(d_{002}\right)$, 結晶子サイズ $(L c$ と $L a)$, および黒鉛化度 $P_{1}$ を要約した。サンプル $\mathrm{A} \sim \mathrm{E}$ の高温電気抵抗率の温度依存性

\section{をFig. 12示す。}

常温での電気抵抗率は, サンプル $\mathrm{C}>\mathrm{D} \gg \mathrm{E}, \mathrm{B}, \mathrm{A}$ の順番で あった。ただし，2種類のフィラーコークスを混合して調製さ れたサンプルEは黒鉛化度の結果からすると, サンプル Aおよ びBよりも低い常温電気抵抗率を示すことが期待されたが，サ ンプルEの常温での抵抗率は，サンプル $\mathrm{A}, \mathrm{B}$ とほほ同程度で あった。しかしながら，これら五つのサンプルの常温での電気 抵抗率の值は，平均面間隔 $d_{002}$ の值より黒鉛化度 $P_{1}$ に相関があ る。抵抗の極小相対值とその温度，ならびに高温域での電気抵 抗が温度上昇とともに増加していく際の傾きには，サンプルの
Table 1 Specification and XRD structural parameters of isotropic graphite samples prepared via cold isostatic pressing (CIP). Reprinted from Ref. 25.

\begin{tabular}{lccccc}
\hline \multicolumn{1}{c}{ Code } & A & B & C & D & $\mathbf{E}$ \\
\hline Coke & Fine & Fine & Ultra fine & Fine & Mixture \\
Additive & $\times$ & $\times$ & $\times$ & $\bigcirc$ & $\times$ \\
$d_{002}[\mathrm{~nm}]$ & 0.3368 & 0.3369 & 0.3376 & 0.3362 & 0.3360 \\
$L c[\mathrm{~nm}]$ & 45 & 38 & 27 & 62 & 73 \\
$L a[\mathrm{~nm}]$ & 54 & 51 & 31 & 54 & 60 \\
$P_{1}$ & 0.50 & 0.50 & 0.35 & 0.45 & 0.54 \\
\hline
\end{tabular}

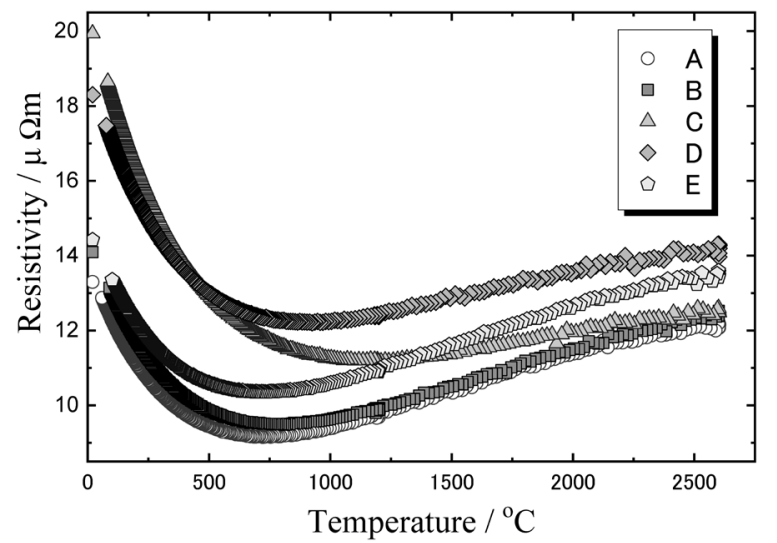

Fig. 12 Temperature dependences of resistivity of the 5 isotropic graphite samples prepared via cold isostatic pressing (CIP). Reprinted from Ref. 25.

違いが明確に表れている。例えば， $d_{002}$ 值が比較的大きいサン プル C は，極小相対值 $\left(R_{\min } / R_{\mathrm{RT}}\right)$ が最も小さく，黒鉛化度 $P_{1}$ が 高いサンプルEの高温域における抵抗の温度依存性の傾きは大 きい。これらの結果は，押出し材で調査した高温抵抗の温度依 存性の結果 ${ }^{24)}$ と一致する。

これら 5 種類の等方性グラファイト材料の熱伝導性に関する 試験結果および考察は，次項で紹介する。

\section{2 熱拡散率 25$), 34)$}

熱伝導性の計測として，本研究ではJIS R1611：2010「ファ インセラミックスのフラッシュ法による熱拡散率・比熱容量 · 熱伝導率の測定方法 ${ }^{35)}$ に準拠した装置を使用した。アドバン ス理工株式会社製のレーザーフラッシュ法熱定数測定装置： TC1200RH（常温と $500{ }^{\circ} \mathrm{C}$ ), TC7000-UVH（高温用：1000 $2600^{\circ} \mathrm{C}$ ）の2種類を用いた。後者は，前述した大工試での共同

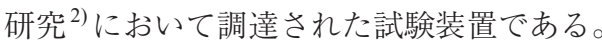

高温用の測定装置の電気炉内部の様子を Fig. 13 に示す。サ ンプルは直径 $10 \mathrm{~mm}$ ，厚さ $2 \mathrm{~mm}$ の円盤である。熱伝導熱源は, 発振波長 $694.3 \mathrm{~nm}$ のルビーレーザーを用い，発振時間は $0.5 \mathrm{~ms}$ 以下とした。目的の温度まで加熱した後レーザーを照射し，照 射後の底面の温度変化を光温度計で計測した。電気炉内の雲囲 気は，常温は大気中， $500{ }^{\circ} \mathrm{C}$ 窒素中， $1000{ }^{\circ} \mathrm{C}$ 以上はアルゴ ンガス中である。

本来ならば，熱拡散率のほかに比熱容量を各試験温度で測定 し，サンプルのかさ密度とそれらの積から熱伝導率を求めたい 
ところであるが，炭素材料の場合，比熱容量が計測温度の関数 であることが知られている。さらに，超高温における比熱容量 の測定は非常に難しい。そこで，筆者の一連の研究では高温の 熱伝導現象として熱拡散率のみを計測し, 計測が可能な常温か ら $500{ }^{\circ} \mathrm{C}$ までは比熱容量を測定している。

ちなみに，比熱容量測定の標準物質として等方性グラファイ 卜材料(IG110)が用いられ，筆者の所属する産業技術総合研究 所計量標準総合センターにおいて標準供給をしている。示差走

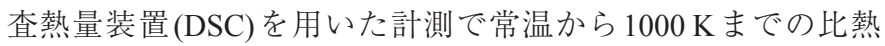
容量の温度依存性（式(2)）を公表している ${ }^{36) 。 ま た ， ~} 1000 \mathrm{~K}$ 以上の高温での比熱容量の值は，グラファイト材料の物性が 要約されている非常に有名な著作本B.T. Kelly著のPhysics of graphite $^{37)}$ にある式(3)が $1000 \mathrm{~K}$ から $2500 \mathrm{~K}$ の温度範囲であれ ば妥当な数值を与える。

$$
\begin{gathered}
C_{\mathrm{p}}=-0.39119+4.6281 \times 10^{-3} T-3.1676 \times 10^{-6} T^{2} \\
+7.1481 \times 10^{-10} T^{3}\left[\mathrm{JK}^{-1} \mathrm{~g}^{-1}\right] \\
(T: 200 \sim 1000 \mathrm{~K})
\end{gathered}
$$$$
C_{\mathrm{p}}=23.48+12.45 \times 10^{-4} \mathrm{~T}-308.67 \times 10^{4} \mathrm{~T}^{-2}
$$$$
+517 \times 10^{10} T^{-2} \exp (-3600 / T)\left[\mathrm{JK}^{-1} \mathrm{~mol}^{-1}\right]
$$

$$
(T: 1000 \sim 2500 \mathrm{~K})
$$

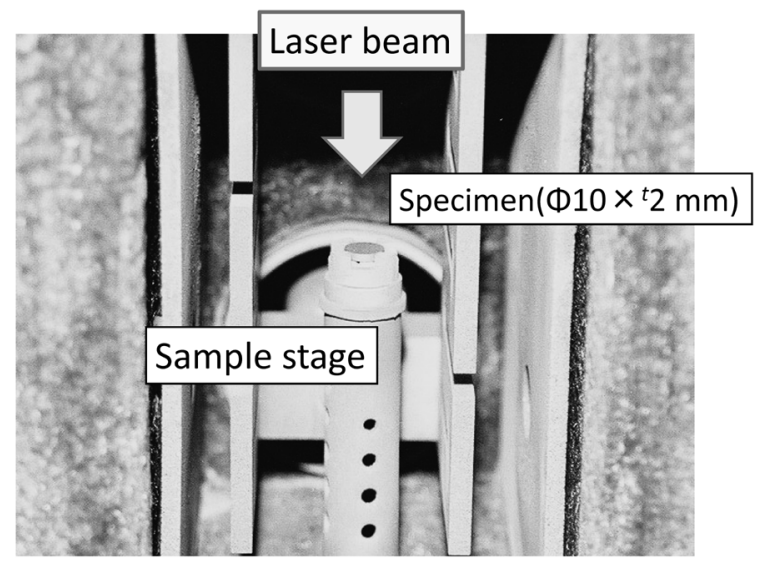

Fig. 13 Photo of sample holding jig in the furnace of test instrument for measurement of thermal diffusivity under a high temperature. This photo is taken the molder cover removed from the top of specimen.

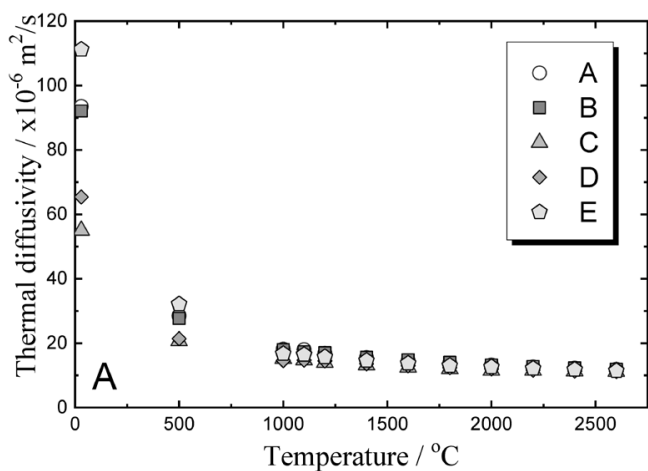

前項からの続きにもどると，等方性グラファイト材料 $(\mathrm{A} \sim \mathrm{E})$ の熱拡散率の温度依存性を Fig. 14 に示す。常温での熱拡散率 の值は, サンプル $\mathrm{E}>\mathrm{A}, \mathrm{B} \gg \mathrm{D}>\mathrm{C}$ の順番となっている。これは, 黒鉛化度 $P_{1}$ と非常に良い相関がある。常温から高温になると 等方性グラファイトブロックの熱拡散率は，急減に低下し，試 験温度 $500{ }^{\circ} \mathrm{C}$ で熱拡散率は常温の半分以下となる。 $1000{ }^{\circ} \mathrm{C}$ 以 上の高温での熱拡散率は，常温での測定值の $1 / 3$ から $1 / 5$ 程度 しかない。そこで，1000 ${ }^{\circ} \mathrm{C}$ 以上を Fig. 14B に拡大した。

温度上昇による熱拡散率の低下が最も著しいのは，黒鉛化度 が高いサンプルEであり，温度上昇による熱拡散率の変化が最 も小さいのがサンプルCである。この結果は，高温抵抗の温度 依存性において，極小值を超えた高温域における高温抵抗の温 度上昇にともなう増加の傾きの大きさの順番と合致している。 これらの結果は，高温域における電気抵抗および熱伝導現象の 両方の温度変化が格子振動によって影響されているという考え を支持する。

他方，人造グラファイト材料の電気抵抗が室温から $600{ }^{\circ} \mathrm{C}$ 付 近まで温度上昇とともに低下する現象と，熱拡散率の温度依存 性は合致しない。これは，電気抵抗が電導キャリアである $\pi$ 電 子または正孔の「ふるまい」であるが，熱伝導は，C-Cの $\sigma$ 結 合の格子振動，すなわち音子（フォノン）の「ふるまい」であ り，現象を伝導するキャリアがそれぞれ異なるためである。

原子炉用カーボン材料，炭素繊維および黒鉛化フィルムにお いて，常温での熱伝導性と電気抵抗率の間には良い相関性があ ることが多くの研究者によって報告されている ${ }^{38)}$ 。しかしなが ら，人造グラファイト材料の熱伝導性と電気抵抗の常温以上の 温度依存性は，まったく異なることに留意していただきたい。 熱伝導性は，その温度依存性も含めて試料内の温度変化を計測 して評価するべきである。

ただし，熱伝導性の計測試験は，非常に難しい。レーザーフ ラッシュ法による熱伝導性の測定方法は，非常に小さい試験片 を用いて熱伝導の方向の熱損失を少なくする工夫がなされてい る。しかしながら，あまりにも試験片が小さ過ぎて，特に，電 炉用人造グラファイト電極の熱伝導性の評価には，適さない。 そこで，筆者らは，次章で紹介する熱膨張率を計測するときに 使用する試験片形状で試料内の温度变化を計測する手法を試み

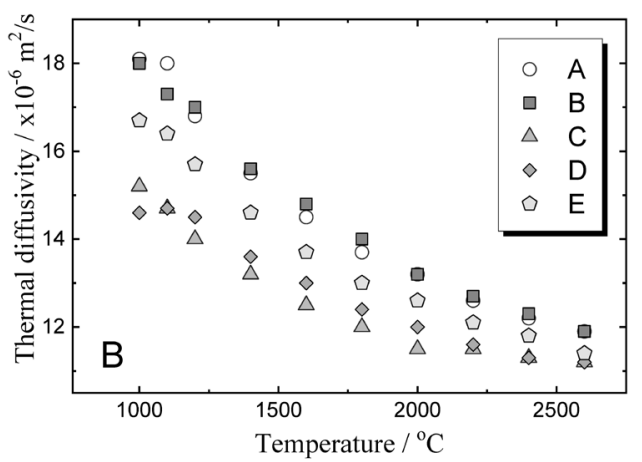

Fig. 14 Temperature dependences of thermal diffusivity of the 5 isotropic graphite samples prepared via cold isostatic pressing (CIP). A: from room temperature (RT) to $2600{ }^{\circ} \mathrm{C}$, B: enlarged from 1000 to $2600{ }^{\circ} \mathrm{C}$. Reprinted from Ref. 25 . 
ている ${ }^{34)}$ 。

\section{5. 熱膨張の計測 ${ }^{39-43)}$}

高温での耐火物などの熱膨張を試験する方法は，JIS R2207: 2007 「耐火物の熱膨張の試験方法」44) で規格化されている。こ の規格には，レーザー光走査型寸法測定器を用いた非接触法 (第1部) と熱機械分析装置(Thermal Mechanical Analysis, TMA) に代表される棒状試験片を用いる接触法（第3 部）が記載され ている。レーザー光走査型寸法測定器 (laser micro-gage, LMG) を用いた非接触法の熱膨張率の測定は, 超高温では電気炉から の放射光が強烈で受光部に散乱光が入り込むため，これまでは $1800{ }^{\circ} \mathrm{C}$ 程度までの温度が上限であった。

筆者は，発熱体から計測ジグだけでなく，参照物質にも高密 度等方性グラファイトを用いた超高温用の熱膨張計測装置を 開発した。比較的新しい成果であり，本誌で詳しく紹介してい る ${ }^{39)}$ 。この装置は，接触法と非接触法が同時に計測できる設計 としたところに特徴がある。この装置の試験片は，直径 $20 \mathrm{~mm} \times$ 長さ $100 \mathrm{~mm}$ の丸棒とした。これは，JIS R7222-2017「黒鉛素材 の物理特性測定方法」45) のサンプリングに準拠したサイズであ る。

LMGのレーザービーム幅は $150 \mathrm{~mm}$ であり，長さ $100 \mathrm{~mm}$ の 試験片の上部と下部にそれぞれビームが照射されるように電気 炉の外側から試験片を保持するジグに穴を準備した。そして， 電気炉の温度を常温から $2400{ }^{\circ} \mathrm{C}$ ま゙の試験片の寸法変化を連 続的に計測した，ちなみに，昇温および降温速度は， $10^{\circ} \mathrm{C} /$ 分 とした。

この試験装置の参照物質としている等方性グラファイト材料 IGS743の線熱膨張率および熱膨張係数の温度依存性曲線を Fig. 15 に示す。線熱澎張率の計測は, 同じ試験片で2 3 回行って, 温度依存性を多項式近似して平均曲線を得た。このように熱膨 張率を多項式で平均化する手法は, ASTM E228法 ${ }^{46)}$ に準拠し て等方性グラファイト材料 G348の線熱膨張率の温度依存性を 計測しているSwank ${ }^{47)}$ も採用している。彼らは二次関数を 採用しているが，筆者は，三次関数を用いた。

カーボン材料の熱膨張挙動は，グラファイト結晶の配向に よって異方性を示すことが知られている。 Morgan ${ }^{48)}$ や Kelly ${ }^{37)}$ のレビューでは，グラファイト結晶の基底面内（ $a$ 軸）方向と 積層（ $c$ 軸）方向の極低温から $3000{ }^{\circ} \mathrm{C}$ までの熱膨張挙動が紹 介されている。特に, 基底面内の熱膨張は, 極低温から $500^{\circ} \mathrm{C}$ 付近まで負の熱膨張挙動を示す特徵がある。

Fig. 16 には，等方性グラファイト材料および電炉用人造グラ ファイト電極を機械的に接続するために使用するニップル材の 押出成形方向と平行 (Parallel) と垂直方向 (Vertical)にサンプリン グした試験片の熱澎張係数の温度依存性を示す ${ }^{40), 41) 。 こ の ニ ッ ~}$ プル材は，高配向性のニードルコークスを主原料にして押出成 形によって調製された素材であるために, Parallel方向の試験 片の場合，炭素六角網面の配向が熱膨張の計測方向と合致して いるために，常温から $500{ }^{\circ} \mathrm{C}$ 付近までは負の熱膨張係数(CTE)

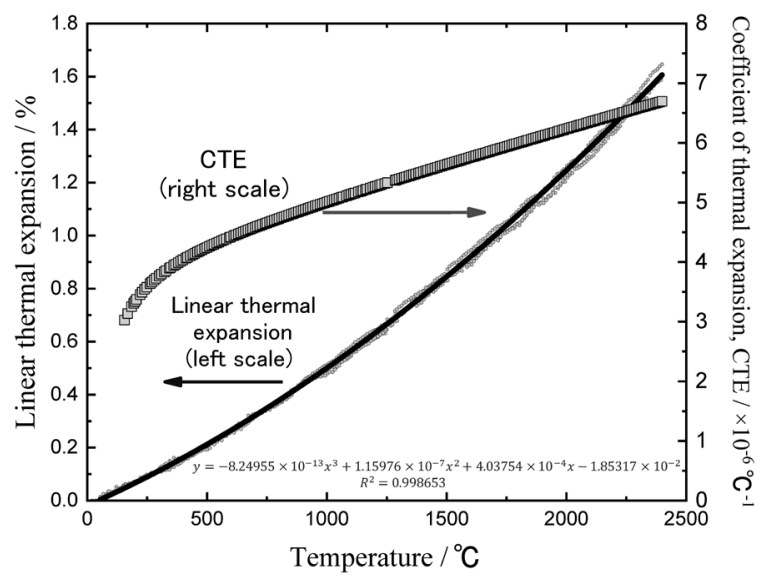

Fig. 15 Measurement and analysis date of thermal expansion of isotropic graphite IGS743. Circle plots: linear thermal expansion measured by the developed device, Solid curve: averaged by polynomial approximation with a cubic function, and square plots: coefficient of thermal expansion estimated from the averaged curve.

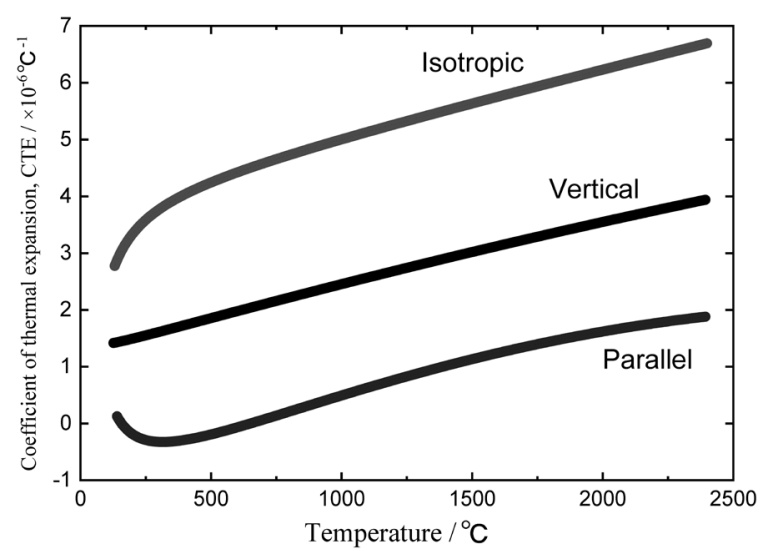

Fig. 16 Temperature dependences of coefficient of thermal expansion of three specimens of artificial graphite products.

が観察されている。すなわち，この温度帯ではわずかな熱収縮 が生じている。他方，押出方向に対して垂直にサンプリングし たVerticalは，常温から高温まで単調な熱澎張係数の増加曲線 となっている。すなわち，人造グラファイト電極の押出方向と 径方向において熱澎張挙動が異なる結果が開発した試験装置か ら得られた。

市販されている熱膨張計測装置の試験片サイズは， $\phi 6 \mathrm{~mm} \times$ $\mathrm{L}_{2} 20 \mathrm{~mm}$ 程度であり，電炉用人造グラファイト電極の原料であ るニードルコークスの組織状態を反映した熱膨張挙動を計測す るには非常に小さ過ぎる。これが，比較的大きな試験片でしか も $2000{ }^{\circ} \mathrm{C}$ 超えた高温域まで熱澎張を計測できる装置を筆者 が開発したモチベーションであった。

等方性グラファイト材料の熱膨張係数の温度依存性は, $500{ }^{\circ} \mathrm{C}$ を境に，それ以下とそれ以上の温度では挙動が異なる。 これは，500 ${ }^{\circ} \mathrm{C}$ 以下の熱膨張にはグラファイト結晶の基底面内 方向の負の熱膨張の挙動が含まれるためだと推察している。

異方性が著しく強い炭素材料の典型として炭素繊維があげら れる。山田，渡辺および筆者は，直接通電加熱法による炭素繊 

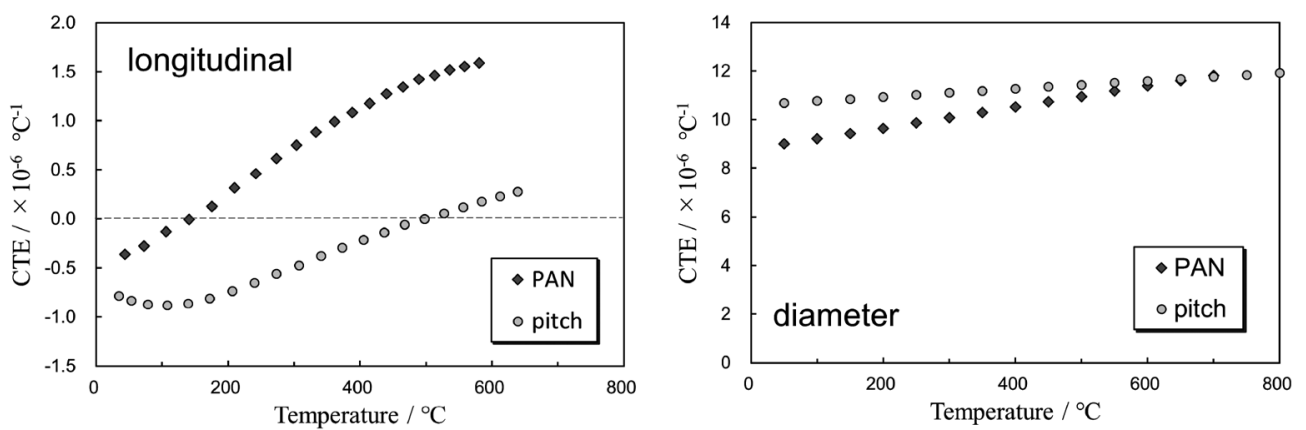

Fig. 17 Temperature dependences of coefficient of thermal expansion of two carbon fibers with different directions, longitudinal and diameter.

維の熱澎張挙動を計測する装置を試作して，様々な炭素繊維

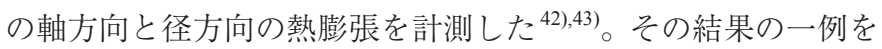

Fig. 17 に示す。

炭素六角網面が強く配向した繊維軸方向では，常温付近から 負の熱膨張挙動が観察される。特に, 高弾性率タイプのピッチ 系炭素繊維は, PAN系より顕著な負の熱膨張が観察されてい る。他方, 径方向の熱膨張係数は, 常温から正の熱膨張で, 繊 維軸方向より絶対值で 1 桁以上大きい值であった。先に紹介し たように，ニードルコークスから調製されたニップル電極の熱 膨張の異方性と同様な結果が示されている。

材料力学特性, 電気抵抗, 熱伝導だけでなく, 熱膨張挙動に も炭素材料の配向，結晶性などが強く影響することがこれらの 試験結果から示された。

\section{6. まとめ}

炭素材料の種々の物性の温度依存性は，常温から数百 ${ }^{\circ} \mathrm{C} の$ 温度域の計測結果を延長してさらなる高温域の挙動を推察する ことが難しいことをこの報告によって理解していただいたと思 う。人造グラファイト材料の高温物性を把握するには，応用展 開する温度域での值を計測することが最も近道である。そのた め，筆者は $2000{ }^{\circ} \mathrm{C}$ 超えた高温での物性計測に強くこだわっ た。また，工業用に用いられる人造グラファイト材料の比較的 大きな組織を反映するだけの試験片サイズにも十分考慮するよ うにした。

超高温での計測が可能になったことから，炭素化焼成した試 料の高温熱処理，すなわち黒鉛化プロセス中の物性変化も計測 できることに気づかれた読者も多くいると思われる。実際に， 筆者は炭素化焼成品の高温熱処理時の物性変化をその場計測し

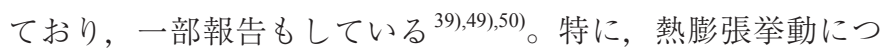
いては，工業的な黒鉛化プロセスにおいて生じる異常な熱膨張 によるグラファイト製品に亀裂が生じるパフィング (puffing) と いう現象 ${ }^{51), 52)}$ の解析につながる可能性がある。これらの成果 については，引き続き計測と解析を行い，いずれ報告したい。

人造グラファイト材料の高温物性の温度依存性に及ぼす調製 条件や結晶構造パラメータの影響を調べるためには，カーボン メーカーからのサンプルやアイデアの提供なしには成し遂げら れなかった。この場を借りて感謝の意を述べたいと思う。
ここで紹介した超高温域の物性計測技術の開発とその試験 データの解析結果が工業プロセスの最適化など人造グラファイ ト材料に関連した産業への技術革新に役立てば幸甚である。

\section{文 献}

1) N. Murofushi, TANSO 2011 [No. 248] 105-111 [in Japanese].

2) 官民連带共同研究報告書「炭素抢よび炭素ハイブリッド複合材 料の物理特性の評価・向上に関する研究」, 大阪工業技術試験所 (1992).

3) N. Iwashita, Zairyo Shiken Gizyutsu (Journal of Material Testing Research Association of Japan) 55 (2011) 76-80 [in Japanese].

4) N. Iwashita, Carbon2011, Shanghai, China, 2011.7.25-29, No. 154.

5) T. Maruyama, M. Eto and T. Oku, Carbon 25 (1987) 723-726.

6) S. Mrozowski, Proceedings of First and Second Conference of Carbon (1956) p. 195, The Waverly Press, New York

7) W. V. Kotlensky, Carbon 4 (1966) 209-214.

8) G. M. Jenkins, Carbon 7 (1969) 9-14.

9) M. Narisawa, M. Adachi and I. Souma, Carbon 30 (1992) 815-817.

10) M. Narisawa, M. Adachi and I. Souma, J. Mater. Sci. 29 (1994) 708-713.

11) 岩下哲雄, 薄葉秀彦, 第4 3 回炭素材料学会年会要旨集, 千葉, 2016.12.7-9, 3C14.

12) N. Iwashita, Zairyo Shiken Gizyutsu (Journal of Material Testing Research Association of Japan) 53 (2008) 241-246 [in Japanese].

13) N. Iwashita, Progress of composites 2008 in Asia and Australasia (Proceedings of ACCM-6), (2008) pp. 439-442.

14) N. Iwashita, Zairyo Shiken Gizyutsu (Journal of Material Testing Research Association of Japan) 55 (2011) 173-178 [in Japanese].

15) N. Iwashita, H. Yamauchi and S. Suzuki, Zairyo (Journal of The Society of Materials Science, Japan) 61 (2012) $462-467$ [in Japanese].

16) 岩下哲雄, 森川文人, 薄葉秀彦, 第36回炭素材料学会年会, 仙台, 2009.12.1-3, 1C08.

17) S. Mizushima, TANSO 1959 [No. 3] 95-98 [in Japanese].

18) O. Yoshimoto, M. Okada and N. Ohta, TANSO 2015 [No. 268] 166-170 [in Japanese].

19) M. Okada, O. Yoshimoto, M. Tatsumi and N. Ohta, TANSO 2016 [No. 271] 2-9 [in Japanese].

20) M. Okada, N. Ohta, O. Yoshimoto, M. Tatsumi and M. Inagaki, Carbon 116 (2017) 737-743.

21) A. I. Lutcov, V. I. Volga and B. K. Dymov, Carbon 8 (1970) 753-760.

22) S. G. Bapat and H. Nickel, Carbon 11 (1973) 323-327.

23) S. G. Bapat, Carbon 11 (1973) 511-514.

24) N. Iwashita, H. Imagawa and W. Nishiumi, Carbon 61 (2013) 602-608.

25) 森川文人, 薄葉秀彦, 岩下哲雄, 日本学術振興会第 117 委員会設 立70周年記念誌「炭素材料の新展開」（川口雅之編）(2018) pp. 
157-160.

26) M. Adachi, H. Shioyama, M. Narisawa, S. Ikeda, K. Tatsumi, I. Souma, H. Isozaki, K. Egawa, H. Kyutoku and T. Tanamura, TANSO 1991 [No. 146] 33-36 [in Japanese].

27) JIS R7651:2007「炭素材料の格子定数および結晶子の大きさ測定方 法」

28) The 117 committee of the Japan Society for the Promotion of Sciences, TANSO 2006 [No. 221] 52-60. [in Japanese].

29) N. Iwashita, C. R. Park, H. Fujimoto, M. Shiraishi and M. Inagaki, Carbon 42 (2004) 701-714

30) B. E. Warren, Phys. Rev. 59 (1941) 693-698.

31) C. R. Houska and B. E. Warren, J. Appl. Phys. 25 (1954) 1503-1509.

32) T. Noda, M. Iwatsuki and M. Inagaki, TANSO 1966 [No. 47] 14-23 [in Japanese].

33) N. Iwashita, Materials Science and Engineering of Carbon: Characterization, Chapter 2: X-ray Diffraction, (M. Inagaki and F. Kang, eds.) (2016) Elsevier and/or (2017) Tsinghua University Press pp. 7-25.

34) 岩下哲雄，天橋弘明，西海 亘，山中健司，矢野 賢，日本学術 振興会第 117 委員会第328 回研究会, 2018.11.16, 117-328-B-1.

35) JIS R1611: 2010「ファインセラミックスのフラッシュ法による熱 拡散率・比熱容量・熱伝導率の測定方法」

36) 阿部陽香，平成 28 年度固体熱物性クラブ全体会合資料，秋葉原 2017.2.3.

37) B. T. Kelly, Physics of Graphite (1981), Applied Science, London.
38) J. G. Lavin, D. R. Boyington, J. Lahijani, B. Nysten and J.-P. Issi, Carbon 31 (1993) 1001-1002.

39) N. Iwashita, TANSO 2015 [No. 268] 135-137 [in Japanese].

40) 岩下哲雄，第44回炭素材料学会年会，桐生，2017.12.6-8, 1 C04.

41) N. Iwashita, Carbon2018, Madrid, Spain, 2018.7.1-6.

42) N. Iwashita, H. Watanabe, O. Yamada, Carbon2016, State College, USA, 2016.7.10-15

43) 岩下哲雄，渡辺博道，山田修史，炭素繊維炭素繊維複合材料の未 来（塩谷正俊監修）(2018) pp. 102-106, S\&T 出版，東京.

44) JIS R2207: 2007 「而火物の熱膨張の試験方法」

45) JIS R7222: 2017 「黒鉛素材の物理特性測定方法」

46) ASTM E228 "Standard test method for linear thermal expansion of solid materials with a push-rode dilatometer".

47) W. D. Swank, F. I. Valentin, M. Kawaji and D. M. McEligot, Nucl. Technol. 199 (2017) 103-109.

48) W. C. Morgan, Carbon 10 (1972) 73-79.

49) N. Iwashita, Carbon2014, Jeju ICC, Korea, 2014.6.29-7.4.

50) 岩下哲雄, 日本学術振興会第117委員会第311 回研究会，2014.9.12, 117-311-B-1.

51) I. Mochida, K. Fujimoto and T. Oyama, Chemistry and physics of Carbon, Vol. 25 (P. A. Thrower, ed.) (1994) pp. 111-209, Marcel Dekker, New York

52) W. Frohs and F. Roessner, TANSO 2015 [No. 267] 77-83. 